\title{
Market Chain Analysis of Orange: A Case Study in Udalguri District of Assam
}

\author{
Pallavi Deka $^{1}$, Sinki Barman ${ }^{2 *}$ and Debasish Borah ${ }^{1}$ \\ ${ }^{1}$ Krishi Vigyan Kendra, Udalguri, Assam, India \\ ${ }^{2}$ Krishi Vigyan Kendra, Nagaon, Assam, India \\ *Corresponding author
}

\section{Keywords}

Marketing channels, Orange, Market

efficiency,

Preharvest

contractor

\section{Article Info}

Accepted:

15 October 2020

Available Online:

10 November 2020

\section{A B S T R A C T}

\section{Introduction}

Agriculture plays a vital role in the economy of Assam. Over 70 percent of the state's population relies on agriculture as farmers, as agricultural labourers, or both for their livelihood. Assam has the unique distinction to grow almost all the varieties of fruits and vegetables. Horticultural sector is yet one of the major source of generating adequate income. There are various kinds of horticultural crops like fruits, vegetables, spices, nuts, tuber crops and medicinal \& aromatic plants etc. Assam falls under the world citrus belt. Orange is grown in all the districts of Assam. In Assam, Tinsukia, NC Hills, Karbi-Anglong, Goalpara, Kamrup, Udalguri, Sonitpur and Chirang are the growing and potential belts of orange. The area under this crop is 7167 ha and the productions is $79496 \mathrm{MT}$ with a productivity of $11092 \mathrm{~kg} / \mathrm{ha}$ in Assam.

The Udalguri district is in fact one of the major producer of orange both in terms of area and production in Assam. The area under this crop in the district is 326 hectares including new plantations and the production 
is 3426 MT with a productivity of $10510 \mathrm{~kg}$ per hectares. Major areas of orange orchards in Udalguri district are Bhairabkunda, Dimakuchi, Doifang, Majbat etc.

Marketing of orange is more complicated as majority of the farmers are illiterate and unorganized with less time to evaluate the marketing of their produce followed by low bargaining power forced to sell at low prices. The present study, therefore, draw attention to analyze the type of marketing channels, marketing cost and margin of market intermediaries, price spread and net price received by producer.

\section{Materials and Methods}

The present study was conducted in Udalguri district of Assam. The field investigation was started in last week of October, 2018 and was completed by the first week of January 2019, thus data collected pertaining to the year 2018-2019. Purposive sampling technique is applied in the present study in selecting the villages. Doifang, Majbat, Dimakuchi and Bhairabkunda regions were purposively opted because of its high economics in production and marketing of orange and a sample of 80nos. orange growers were randomly selected to estimate marketing margin, marketing efficiency, market cost involved and marketing channels. The primary data were collected with the help of specially designed pre-tested schedules through personal interview with the respondents. Inorder to estimate the marketing efficiency, marketing margin of different market intermediaries and to determine price spread in different marketing channels, 10 preharvest contractors, 10 retailers and 5 wholesalers were selected in the present study.

Different analytical tools used in the study were as follows:

\section{Marketing cost}

$\mathrm{Tc}=\mathrm{Cp}+\mathrm{Mci}$

Where,

Tc: Total cost of orange marketing

$\mathrm{Cp}$ : Cost incurred by producer

Mci: Marketing cost increased by $i^{\text {th }}$ middleman

\section{Marketing margins}

$\mathrm{Ami}=\mathrm{Pmi}-(\mathrm{Pp}+\mathrm{Mci})$

Where,

Ami: The absolute margin of the ith middleman

Pmi: The selling price of the ith middleman

Pp: Producer's price for his produce

Mci: Marketing cost of the $i^{\text {th }}$ middleman

Price spread $=$ Consumer price - Producer price

Marketing efficiency: Marketing efficiency was calculated using Acharya and Agarwal (1998).

$\mathrm{ME}=\mathrm{Pp} /(\mathrm{TMC}+\mathrm{TMM}) \times 100$

Where,

ME: Marketing efficiency

Pp: Producer's price

TMC: Total marketing cost

TMM: Net marketing margin

\section{Producer's Share in Consumer Rupee}

$\mathrm{Ps}=(\mathrm{PF} / \mathrm{PC}) \times 100$

Where,

$\mathrm{PF}=$ price received by the farmer

$\mathrm{PC}=$ price paid by the consumer Where,

Ps: Producer's share in consumer's rupee 
Pp: Producer's price for his vegetables produce

Pc: Price paid by consumer

\section{Results and Discussion}

\section{Marketing system and channels}

Marketing plays an important role in stimulating production and consumption and speeding up the economic development of the country. The horticultural marketing in India is extremely decentralized. The marketing of horticultural crops is quite complex and risky because of its perishable nature, seasonality and bulkiness. Cultivation of horticultural crops is more profitable than any other seasonal crops. Marketing of horticultural crops in Assam is unorganized and involves intermediaries such as wholesalers, retailers, village merchants and others.

Two channels for marketing of Orange were identified in the study area:

Channel I: Producer-Pre harvest ContractorRetailer-Consumer
Channel II: Producer- Pre harvest ContractorWhole seller-Retailer-Consumer

The marketing of Orange in the district is mostly dominated by pre harvest contractor. One of the most common and often worst systems in the marketing of fruit orange is the emergence of pre-harvest contractors who take place of the owners of the orchard in maintenance and for making harvesting and marketing arrangements (Mahanta and Konwar, 2014). In most cases the contractors agree to pay a fixed sum prior production for the entire crop by assuming the risk of damage to the crop by adverse climatic condition. The producers have to sell their produce on contract basis to pre-harvest contractors due to lack of transportation facilities and cold storage. Adequate and efficient transportation is a cornerstone for the modern marketing system (Kohls and Uhl, 2005). More than 83.75 per cent produce was marketed through channel I. In channel II, only 16.25 per cent producers sold their produce through this channel. The result is in conformity with findings of (Mahanta and Konwar, 2014).

Table.1 Marketing Cost, marketing margin, price spread and marketing efficiency under different channels (per kg)

\begin{tabular}{|l|l|c|c|}
\hline Sl. No. & \multicolumn{1}{|c|}{ Particulars } & \multicolumn{2}{c|}{ Marketing channels } \\
\cline { 3 - 4 } & & C-I & C-II \\
\hline $\mathbf{1}$ & Gross price received by farmer (Rs. Per Kg) & 35 & 32 \\
\hline $\mathbf{2}$ & Cost incurred by farmers (Rs. Per Kg) & 0.48 & 0.55 \\
\hline $\mathbf{3}$ & Producer's Net price & 34.52 & 31.45 \\
\hline $\mathbf{4}$ & Marketing cost incurred by Farmers (Rs. Per Kg) & - & - \\
\hline $\mathbf{5}$ & Consumers price (Rs. Per Kg) & 58 & 65 \\
\hline $\mathbf{6}$ & Price Spread (Rs. Per Kg) & 20 & 22 \\
\hline $\mathbf{7}$ & Total gross marketing margin (Rs. Per Kg) & 20.48 & 22.55 \\
\hline $\mathbf{8}$ & Marketing Margin as \% of consumers price & 2.83 & 2.88 \\
\hline $\mathbf{9}$ & Producer's share in consumers rupee & 59.52 & 48.38 \\
\hline $\mathbf{1 0}$ & Marketing efficiency & 1.71 & 1.42 \\
\hline
\end{tabular}


In both the channels, farmers did not incur any marketing cost. However, total marketing cost is higher in case of channel II (Rs.22.55/kg) as compared to channel I (Rs.20.48). From the Table 1, it was revealed that the total marketing margin in channel I was low compared to channel II and also producers share in consumer's rupee was highest in channel-I (59.52) where less intermediaries were involved. Thus, channel I is the more preferable in terms of consumers and producers both. The findings is in conformity with Barman et al., (2019).The market efficiency was found to be high in channel I with 1.71 per cent compared to channel II (1.42 per cent) as there is more market intermediaries present in this channel II. Therefore it is concluded that channel $\mathrm{I}$ is performing better than channel II. The findings is in conformity with Gunwant et al., (2013) and Vallapu Sateesh et al., (2018).

In conclusion the production and marketing of orange in the study area is highly remunerative. Present study has found that farmers face problems in marketing due to poor roads conditions, lack of storage facilities etc. Therefore producers are hesitating to bring their produce themselves in the market and the marketing system is dominated by pre harvest contractor. Producers are getting very low price of the consumer's price in case of orange. In order to link the farmers to market for remunerative prices, proper road and other infrastructure should be developed. Pandey et al., (2011) also suggested the same in order to narrow down the spatial price differences between famers and consumers [6]. The above analysis revealed that the produce of orange flowed from hands of producers to hands of consumers through two different channels. The marketing of oranges in the study area has mostly controlled by some intermediaries who exploit the orange producers by purchasing the produces at a very lower price and sale it to the consumers at higher price. Keeping in view the problems faced by the orange growers in the study area, formation of Farmer's Producers Organizations (FPOs), organizing training programmes, provision of institutional credit and loan should be initiated.

\section{References}

Acharya SS and Agarwal NL (2004). Agricultural Marketing in India.New Delhi, Oxford and IBN Publishing Co. Pvt.Ltd.

Barman Sinki, Deka N, Deka P.Market Structure of Coconut in Nagaon district of Assam, India. Research Journal of Agricultural Sciences.10(3):537-542

Khols RL, JN Uhl (2005). Marketing of Agricultural Products, 9th ed. Macmillan, New York.http:// www. orange (fruit) wikipedia, the free encyclopedia./E:/orange/html. http://en.wikipedia.org/wiki/value_chain_ management.

Kumar and Mahanta (2014). Production and Marketing of Orange in Assam-A study on Doomdooma Region of Tinsukia District, Journal of Agriculture and Life Sciencesvol.1 No.1.pp.86-90.

PandeyDivya, Kumar A, Singh R. Marketing Of Sweet Orange (Malta) In Kumaon Region Of Uttarakhand. Journal Of Recent Advances In Applied Sciences (Jraas) 26:6-11, 2011

VallapuSateesh et al., (2018). A study on marketing of sweet orange in Nalgonda district of Telangana state. International Journal of Advances in Agricultural Science and Technology, Vol.5 Issue.8, August- 2018, pg. 74-82. ISSN: 23481358.

\section{How to cite this article:}

Pallavi Deka, Sinki Barman and Debasish Borah. 2020. Market Chain Analysis of Orange: A Case Study in Udalguri District of Assam. Int.J.Curr.Microbiol.App.Sci. 9(11): 2020-2023. doi: https://doi.org/10.20546/ijcmas.2020.911.240 